\title{
Studies of Biological Activities of the Roots of Bombax ceiba $\mathbf{L}$.
}

\author{
Md. Hasanur Rahman ${ }^{1}$, Mohammad A. Rashid ${ }^{2}$ and Tofail Ahmad Chowdhury ${ }^{1}$ \\ ${ }^{1}$ Department of Chemistry, University of Dhaka, Dhaka-1000, Bangladesh \\ ${ }^{2}$ Department of Pharmaceutical Chemistry, Faculty of Pharmacy, University of Dhaka \\ Dhaka-1000, Bangladesh
}

(Received: May 13, 2019; Accepted: June 16, 2019; Published: July 22, 2019)

\begin{abstract}
Bioactivities of the methanolic crude extract of root of Bombax ceiba L. and its organic and aqueous soluble partitionates were studied to investigate its medicinal importance. In Free radical scavenging assay by DPPH method, the aqueous soluble partitionate (AQSF) demonstrated the highest free radical scavenging activity with $\mathrm{IC}_{50}$ value of $3.33 \pm 0.25 \mu \mathrm{g} / \mathrm{ml}$. The brine shrimp lethality bioassay of different partitionates of the root demonstrated the significant lethality by the hexane soluble partitionate (HSF) having $\mathrm{LC}_{50}$ value of $1.19 \pm 0.10 \mu \mathrm{g} / \mathrm{ml}$. Among different fractionates of the root, the highest percentage $(44.55 \pm 0.12 \%)$ of clot lysis was exhibited by AQSF. The crude extract revealed promising antidiarrheal, hypoglycemic, central and peripheral analgesic activities at both doses of 200- and 400$\mathrm{mg} / \mathrm{kg}$ body weight in Swiss-Albino rat model.
\end{abstract}

Key words: Bombax ceiba, antioxidant, thrombolysis, diarrhea, hypoglycemic, analgesic.

\section{Introduction}

Bombax is a genus, comprising some 60 species of topical trees in the Bombacaceae family. They are native to western Africa, the Indian subcontinent, Southeast Asia, as well as subtropical regions of East Asia and northern Australia. Bombax ceiba L. (syn. Bombax malabaricum DC. Salmalia malabarica), a medium sized deciduous tree, commonly known as Silk Cotton Tree, Indian Red Kapok tree, Semal, Shimul, Shalmali etc. is also distributed in temperate and tropical Asia (Wang et al., 2013; Verma et al., 2011). It is used in folk medicine for its properties such as demulcent, diuretic, restorative, aphrodisiac and emetic (Faizi and Ali, 1999). It also demonstrated strong antiHelicobacter pylori activity (Wang and Huang, 2005). Its different parts including flowers, roots, stem barks and leaves, etc. have been used for the treatment of diarrhea, dysentery, hepatitis, lymph adenoma and menorrhagia in Taiwan and Kwangton (Ali et al., 2011). Recent study has revealed that the plant possesses strong anti-inflammatory, immunomodulatory, antineoplastic, antioxidant, anticancer, hypotensive, hypolipidemic and antihyperglycemic activities (Wang et al., 2013)

Considering its medicinal importance to the traditional healers the plant was chosen for the investigation of bioactivities. The roots of $B$. ceiba were subjected to different bioassays to determine its biological activities with the aim of establishing the pharmacological basis for its folkloric use against different diseases.

\section{Materials and Methods}

Chemicals and reagents: Gallic acid, tert-butyl1-hydroxytoluene (BHT), streptokinase (Beacon pharmaceutical Ltd.), acetic acid (Merck, Germany), Tween-80 (BDH Chemicals, UK), normal saline (Beximco Infusion Ltd.), diclofenac sodium, glibenclamide and loperamide (Square Pharmaceuticals) were used in this investigation.

Correspondence to: Tofail Ahmad Chowdhury; Tel.: 880-2-9661920-73; Ext. 7147; Fax: 880-9667222; Email: tofailac@yahoo.com

DOI: https://doi.org/10.3329/bpj.v22i2.42313 
Collection and extraction of plant material: The roots of B. ceiba were collected from Natore, Bangladesh in April, 2016 and taxonomic identification was made at the Department of Botany, University of Dhaka. The roots were first dried at room temperature and then in an oven below $40^{\circ} \mathrm{C}$. The dried roots were ground to a coarse powder with a grinder (Cyclotec 200 meshes) and the powder was stored in an airtight bottle used throughout the investigation. The powdered root $(1000 \mathrm{~g})$ was soaked in $3.0 \mathrm{~L}$ of methanol for 7 days and then filtered through a cotton plug followed by Whatman filter paper number 1 . The extract was concentrated at $40^{\circ} \mathrm{C}$ with a rotary evaporator. A portion $(5 \mathrm{~g})$ of the concentrated methanol extract was fractionated by the modified Kupchan partitioning protocol (Van Wagenen et al., 1993) into hexane (HSF), dichloromethane (DCMSF), ethylacetate (EASF) and aqueous (AQSF) soluble materials.

Experimental animal: Swiss-Albino mice of either sex aged 4-5 weeks were used for the experiment. The average weight of the mice was 20$25 \mathrm{~g}$. All efforts were made to minimize animals suffering and to reduce the number of animals used in the experiments. The mice were kept in standard environmental condition (at $24.0 \pm 2{ }^{\circ} \mathrm{C}$ temperature and $60-70 \%$ relative humidity and $12 \mathrm{hrs}$ light/12 hrs dark cycle) for a week for acclimatization after their purchase and fed with rodent feed collected from the International Centre for Diarrheal Diseases and Research, Bangladesh (Icddr'b) and water ad libitum. The experimental animals were randomly divided into four groups (I to IV) consisting of five mice in each group for each bioassay: positive control, negative control and two test groups receiving methanol extract (ME) at doses of 200-(ME1) and 400- $\mathrm{mg} / \mathrm{kg}$ of body weight (ME2).

Total phenolic control analysis: Total phenolic content of B. ceiba was determined using FolinCiocalteu reagent as oxidizing agent following the method described by M. Miah et al. (2018).

Determination of free radical scavenging activity: The free radical scavenging activities of the plant extracts on the stable radical 1,1-diphenyl-2- picrylhydrazyl (DPPH) were estimated by the method of Brand-Williams et al. (1995). The antioxidant potential was assessed from the bleaching of purple colored methanol solution of DPPH radical by the plant extract as compared to that of tert-butyl-1hydroxytoluene (BHT).

Brine shrimp lethality bioassay: The brine shrimp lethality activity of extracts of the roots of Bombax ceiba L. was determined by following the method illustrated by Meyer et al. (1982). Vincristine sulfate was used as reference.

Thrombolytic activity: The thrombolytic activity of all extractives was carried out as per the method reported by Prasad et al. (2007).

Antidiarrheal activity: The antidiarrheal activity of the methanol extract of $B$. ceiba roots was evaluated through castor oil induced diarrhea in mice (Shoba \& Thomas, 2001), where loperamide was used as reference drug.

Hypoglycemic activity: The lowering of blood glucose level of the experimental animals was measured by tail tipping method (Hasan et al., 2015) on Swiss-Albino mice using glibenclamide as standard drug.

Central analgesic activity: The central analgesic activity was determined by tail immersion method following the method described by Chakraborty et al. (2018) using diclofenac sodium as a positive control.

Peripheral analgesic activity: Peripheral analgesic activity was evaluated by determining the ability of the test samples to inhibit acetic-acid induced abdominal writhing in mice (Razan et al., 2016).

For all bioassays, three replicates of each sample were used for statistical analysis and the values have been reported as mean $\pm \mathrm{SD}$ (standard deviation).

\section{Results and Discussion}

The amount of total phenolic content in different extractives of roots of $B$. ceiba ranged from $85.32 \pm$ $0.26 \mathrm{mg}$ to $168.99 \pm 1.02 \mathrm{mg}$ of GAE (Gallic acid equivalent)/g of extractives. Among all the 
extractives, the highest phenolic content was found in AQSF $(168.99 \pm 1.02 \mathrm{mg} \mathrm{GAE} / \mathrm{g}$ of extractives $)$.

Table 1. Total phenolic content of the crude extract and its different partitionates of B. ceiba.

\begin{tabular}{llc}
\hline $\begin{array}{l}\text { Plant } \\
\text { part }\end{array}$ & $\begin{array}{l}\text { Sample } \\
\text { code }\end{array}$ & $\begin{array}{c}\text { Total phenolic content (mg of } \\
\text { GAE/g of extractives) }\end{array}$ \\
\hline \multirow{6}{*}{ Root } & ME & $85.32 \pm 0.26$ \\
& HSF & $94.92 \pm 1.41$ \\
& DCMSF & $107.28 \pm 1.45$ \\
& EASF & $140.26 \pm 0.03$ \\
& AQSF & $168.99 \pm 1.02$ \\
\hline
\end{tabular}

Data are presented as mean \pm SD. BHT $=$ tert-butyl-1hydroxytoluene, $\mathrm{ME}=$ methanol extract, $\mathrm{HSF}=$ hexane soluble fraction, DCMSF = dichloromethane soluble fraction, EASF = ethyl acetate soluble fraction, AQSF = aqueous soluble fraction of the roots of B. ceiba.

In this investigation, the AQSF showed strong free radical scavenging activity with an $\mathrm{IC}_{50}$ value of $3.33 \pm 0.25 \mu \mathrm{g} / \mathrm{ml}$, while the $\mathrm{IC}_{50}$ value of BHT was $61.90 \pm 1.70 \mu \mathrm{g} / \mathrm{ml}$. Other samples ME, HSF, DCMSF and EASF also exhibited antioxidant potential having $\mathrm{IC}_{50}$ value $10.25 \pm 1.97,62.47 \pm$ $2.84,20.80 \pm 1.09$ and $5.98 \pm 2.34 \mu \mathrm{g} / \mathrm{ml}$, respectively (Table 2).

Table 2. Free radical scavenging activity of the roots of B. ceiba.

\begin{tabular}{llc}
\hline Plant part & Sample code & $\mathrm{IC}_{50}(\mu \mathrm{g} / \mathrm{ml})$ value \\
\hline \multirow{6}{*}{ Root } & BHT & $61.90 \pm 1.70$ \\
& ME & $10.25 \pm 1.97$ \\
& HSF & $62.47 \pm 2.84$ \\
& DCMSF & $20.80 \pm 1.09$ \\
& EASF & $5.98 \pm 2.34$ \\
& AQSF & $3.33 \pm 0.25$ \\
\hline
\end{tabular}

Data are presented as mean \pm SD. BHT $=$ tert-butyl-1hydroxytoluene, $\mathrm{ME}=$ methanol extract, $\mathrm{HSF}=$ hexane soluble fraction, DCMSF = dichloromethane soluble fraction, EASF = ethyl acetate soluble fraction, AQSF = aqueous soluble fraction of the roots of B. ceiba.

In brine shrimp lethality bioassay, the highest lethality was demonstrated by $\mathrm{HSF}$ having $\mathrm{LC}_{50}$ value of $1.19 \pm 0.10 \mu \mathrm{g} / \mathrm{ml}$ as compared to $0.47 \pm$ 0.01 for vincristine sulfate whereas ME, DCMSF and
EASF showed moderate cytotoxicity but AQSF showed low activity (Table 3).

Table 3. Brine shrimp lethality bioassay of the root extract of $B$. ceiba.

\begin{tabular}{llc}
\hline Plant & Sample code & LC $_{50}(\mu \mathrm{g} / \mathrm{ml})$ \\
\hline \multirow{4}{*}{ Root } & ME & $67.47 \pm 13$ \\
& HSF & $1.19 \pm 0.10$ \\
& DCMSF & $29.87 \pm 11.17$ \\
& EASF & $93.45 \pm 4.95$ \\
& AQSF & $890.57 \pm 66.67$ \\
& VS & $0.47 \pm 0.01$ \\
\hline
\end{tabular}

Data are presented as mean $\pm \mathrm{SD}$. ME $=$ methanol extract, $\mathrm{HSF}=$ hexane soluble fraction, DCMSF $=$ dichloromethane soluble fraction, EASF = ethyl acetate soluble fraction, $\mathrm{AQSF}=$ aqueous soluble fraction of the roots of $B$. ceiba.

The thrombolytic activity was studied for all the extractives of $B$. ceiba to evaluate its activity as a cardioprotective action. Among different fractionates of $B$. ceiba, the highest percentage of clot lysis 44.55 $\pm 0.12 \%$ was exhibited by AQSF (Table 4 ).

\section{Table 4. Thrombolytic activity of the extractives} of roots of $B$. ceiba.

\begin{tabular}{llc}
\hline Plant part & Sample code & \% Clot lysis \\
\hline \multirow{6}{*}{ Root } & MESF & $21.09 \pm 1.42$ \\
& HESF & $9.56 \pm 1.21$ \\
& DCMSF & $40.67 \pm 0.47$ \\
& EASF & $29.55 \pm 0.22$ \\
& AQSF & $44.55 \pm 0.12$ \\
& Blank & $3.80 \pm 0.34$ \\
& SK & $64.22 \pm 0.66$ \\
\hline
\end{tabular}

Data are presented as mean $\pm \mathrm{SD}$. $\mathrm{ME}=$ methanol extract, $\mathrm{HSF}=$ hexane soluble fraction, DCMSF $=$ dichloromethane soluble fraction, EASF = ethyl acetate soluble fraction, $\mathrm{AQSF}=$ aqueous soluble fraction of the roots of $B$. ceiba, SK = streptokinase.

The methanol extract of the roots of $B$. ceiba revealed significant anti-diarrheal activity in mice model at both doses of $200-$ and $400-\mathrm{mg} / \mathrm{kg}$ bw at the first, second, third and fourth hour (Table 5). 
The crude methanol extract of $B$. ceiba revealed remarkable hypoglycemic activity in Swiss Albino mice at 200- and 400- mg/kg bw. After 180 minutes of administration, the crude methanol extract displayed $44.6 \%$ and $32.5 \%$ reduction of blood sugar level at 200- and $400-\mathrm{mg} / \mathrm{kg}$ of body weight, respectively whereas the standard drug glibenclamide showed 50.36\% reduction of blood glucose level in mice (Table 6).
The methanol extract of $B$. ceiba exhibited strong central analgesic activity in Swiss-Albino mice at both doses of $200-$ and $400-\mathrm{mg} / \mathrm{kg}$ bw after 30, 60 and $90 \mathrm{~min}$ in tail immersion method (Table 7).

The methanol extract of $B$. ceiba showed significant peripheral analgesic activity with percent inhibition of $45.12 \%$ and $62.76 \%$ at 200 - and 400 $\mathrm{mg} / \mathrm{kg}$ bw respectively (Table 8 ).

Table 5. Antidiarrheal activity of the crude methanol extract of B. ceiba.

\begin{tabular}{|c|c|c|c|c|c|c|c|c|}
\hline \multirow{2}{*}{$\begin{array}{l}\text { Animal } \\
\text { group }\end{array}$} & \multicolumn{8}{|c|}{ Number of diarrheal feces (average) } \\
\hline & $1 \mathrm{hr}$ & $\begin{array}{c}\% \\
\text { Reduction }\end{array}$ & $2 \mathrm{hrs}$ & $\begin{array}{c}\% \\
\text { Reduction }\end{array}$ & $3 \mathrm{hrs}$ & $\begin{array}{c}\% \\
\text { Reduction }\end{array}$ & $4 \mathrm{hrs}$ & $\begin{array}{c}\% \\
\text { Reduction }\end{array}$ \\
\hline CTL & 1 & & 3.0 & & 2 & & 2.33 & \\
\hline STD & 0 & 100 & 0.67 & 77.67 & 0.67 & 66.5 & 0.67 & 71.24 \\
\hline ME 1 & 0.33 & 67 & 1.67 & 44.33 & 1 & 50 & 1 & 57.08 \\
\hline ME 2 & 0.33 & 67 & 0.67 & 77.67 & 1 & 50 & 1 & 57.08 \\
\hline
\end{tabular}

$\mathrm{ME}=$ methanol extract of $B$. ceiba, $\mathrm{STD}=$ standard drug loperamide, $\mathrm{CTL}=$ control group $(1 \%$ Tween 80 in normal sline $)$.

Table 6. Hypoglycemic activity of the root of Bombax ceiba.

\begin{tabular}{lcccccccc}
\hline $\begin{array}{l}\text { Animal } \\
\text { group }\end{array}$ & 0 Min & $\begin{array}{c}\% \\
\text { Reduction }\end{array}$ & 60 Min & $\begin{array}{c}\% \\
\text { Reduction }\end{array}$ & 120 Min & $\begin{array}{c}\% \\
\text { Reduction }\end{array}$ & 180 Min & $\begin{array}{c}\% \\
\text { Reduction }\end{array}$ \\
\hline CTL & 5.13 & - & 13.40 & - & 9.50 & - & 8.40 & - \\
STD & 5.03 & 1.94 & 10.20 & 23.88 & 7.40 & 22.05 & 4.17 & 50.36 \\
ME-1 & 4.80 & 6.43 & 11.30 & 15.67 & 6.63 & 30.21 & 4.67 & 44.40 \\
ME-2 & 5.23 & 1.94 & 11.10 & 17.16 & 9.33 & 1.80 & 5.67 & 32.5 \\
\hline
\end{tabular}

$\mathrm{ME}=$ methanol extract of Bombax ceiba, $\mathrm{STD}=$ standard drug glibenclamide $(10 \mathrm{mg} / \mathrm{kg} \mathrm{bw}), \mathrm{CTL}=$ control group $(1 \%$ Tween-80 \& DMSO in normal saline $10 \mathrm{mg} / \mathrm{kg} \mathrm{bw}$ ).

Table 7. Central analgesic activity of the root extractives of $B$. ceiba in Swiss-Albino mice.

\begin{tabular}{|c|c|c|c|c|c|c|c|}
\hline & \multirow{3}{*}{ Sample } & \multicolumn{6}{|c|}{ Average immersion time } \\
\hline & & \multicolumn{2}{|c|}{ After $30 \mathrm{~min}$} & \multicolumn{2}{|c|}{ After $60 \mathrm{~min}$} & \multicolumn{2}{|c|}{ After $90 \mathrm{~min}$} \\
\hline & & $\begin{array}{c}\text { (Average } \\
\text { immersion } \\
\text { time } \pm \text { SD) }\end{array}$ & $\begin{array}{c}\% \\
\text { Elongation }\end{array}$ & $\begin{array}{l}\text { (Average immersion } \\
\text { time } \pm \mathrm{SD})\end{array}$ & $\begin{array}{c}\% \\
\text { Elongation }\end{array}$ & $\begin{array}{c}\text { (Average } \\
\text { immersion } \\
\text { time } \pm \text { SD) }\end{array}$ & $\begin{array}{c}\% \\
\text { Elongation }\end{array}$ \\
\hline \multirow{4}{*}{ Root } & CTL & $2.16 \pm 0.43$ & & $1.87 \pm 0.18$ & & $2.23 \pm 0.32$ & \\
\hline & STD & $6.18 \pm 0.69$ & 186.1 & $9.19 \pm 0.34$ & 391.44 & $13.15 \pm 0.18$ & 489.68 \\
\hline & ME 1 & $3.99 \pm 0.12$ & 84.72 & $7.15 \pm 0.58$ & 282.35 & $8.28 \pm 1.53$ & 271.30 \\
\hline & ME 2 & $3.62 \pm 0.55$ & 67.59 & $7.39 \pm 0.73$ & 295.19 & $9.94 \pm 1.3$ & 345.74 \\
\hline
\end{tabular}

$\mathrm{ME}=$ methanol extract of Bombax ceiba, $\mathrm{STD}=$ standard drug diclofenac $(50 \mathrm{mg} / \mathrm{kg}$ bw), CTL = control group ( $1 \%$ Tween80 in normal saline $10 \mathrm{mg} / \mathrm{kg}$ bw). 
Table 8. Effect of methanol extract of the roots of $B$. ceiba on writhing test in mice.

\begin{tabular}{lccccc}
\hline Animal group & \multicolumn{3}{c}{ Number of writhing } & $\begin{array}{l}\text { Average } \\
\pm \text { SD }\end{array}$ & Inhibition (\%) \\
\cline { 2 - 5 } & M-1 & M-2 & M-3 & $17 \pm 1$ & \\
\hline CTL & 16 & 18 & 17 & $4.33 \pm 0.58$ & 74.53 \\
STD & 4 & 5 & 4 & $9.33 \pm 1.53$ & 45.12 \\
ME 1 & 9 & 11 & 8 & $6.33 \pm 0.58$ & 62.76 \\
ME 2 & 6 & 6 & 7 & 6.38 \\
\hline
\end{tabular}

$\mathrm{ME}=$ methanol extract of Bombax ceiba, $\mathrm{STD}=$ standard drug diclofenac $(50 \mathrm{mg} / \mathrm{kg}$ bw), CTL $=$ control group ( $1 \%$ Tween80 in normal saline $10 \mathrm{mg} / \mathrm{kg} \mathrm{bw}$ ), M-1,2,3 = mouse- 1,2 and 3, respectively.

\section{Conclusion}

B. ceiba was found to be a potential plant for further chemical investigation, since it has significant antioxidant, brine shrimp lethality, thrombolytic, antidiarrheal, hypoglycemic, central and peripheral analgesic activities. The observed biological activities justify some of its traditional uses by the folk practitioner.

\section{Acknowledgement}

The first author expresses his heartfelt gratitude to the Ministry of Science and Technology, People's Republic of Bangladesh for providing financial assistance to this research work through NST fellowship program.

\section{References}

Ali M. El-Hagrassi, Mamdouh M. Ali, Abeer F. Osman and Mohamed Shaaban 2011. Phytochemical investigation and biological studies of Bombax malabaricum flowers. Nat. Prod. Res. 25, 141-151.

Chakraborty, P., Bala, N. and Das, S. 2018. Analgesic Activity of Methanolic Extract of Tubers of Arisaema tortuosum (Wall.) Schott. in Swiss Albino Mice. Dhaka Univ. J. Pharm. Sci. 17, 37-41.

Faizi, S. and Ali, M. 1999. Shamimin: A new flavonol C glycoside from leaves of Bombax ceiba. Planta Medica. 65, 383-385.

Wang, G. K, Lin, B. B, Rao, R., Zhu, K., Qin, X. Y., Xie, G. Y. and Qin, M. J. 2013. A new lignin with antiHBV activity from the roots of Bombax ceiba. Nat. Prod. Res. 27, 1348-1352.
Hasan, M. N., Rahman, M. H., Guo, R. and Hirashima, A. 2015. Hypoglycemic activity of methanolic leaf extract of Blumea lacera in Swiss-albino mice. Asian Pac. J. Trop. Dis. 5, 195-198.

Meyer, B.N., Ferringni N.R., Puam, J.E., Lacobsen L.B. and Nichols D.E. 1982. Drug Inf. J. 31, 516-554.

M.M Miah., Pritom Das., Yeasrin I., Shajib, M.S and Rashid, M.A. 2018. In vitro antioxidant, antimicrobial, membrane stabilization and thrombolytic activities of Dioscorea hispida Dennst. Eur. J. Integr. Med. 19, 121-127.

Prasad, S., Kashyap, R.S., Deopujari, J.Y., Purohit, H.J., Taori, G.M. and Daginawala, H.F. 2007. Effect of Fagonia arabica (Dhamasa) on in vitro thrombolysis, BMC Complement. Alternat. Med. 7, 7-36.

Razan, M., Rahman, M., Tahia, F., Hossain, M. and Rashid, M.A. 2016. Analgesic and Antidiarrheal Activities of Leaf of Podocarpus neriifolius D. Don. Bangladesh Pharm. J. 19, 215-218.

Shoba, F.G. and Thomas, M. 2001. Study of antidiarrhoeal activity of four medicinal plants in castor oil induced diarrhea. J. Ethnopharmacol. 76, 73-76.

Van Wagenen, B.C., Larsen, R., Cardellina, J.H., Ran dazzo, D., Lidert, Z.C. and Swithenbank, C. 1993. Ulosantoin, a potent insecticide from the sponge Ulosa ruetzleri. J. Org. Chem. 58, 335-337.

Verma, S. K., Jain, V. and Katewa, S.S. 2011. Anabolic effect of Bombax ceiba root in indiopathic involuntary weight loss a case study. J. Herbal Med. Toxicol. 5, $1-5$.

Wang, Y. and Huang, T. 2005. Screening of antiHelicobacter pylori herbs deriving from Taiwanese folk medicinal plants. FEMS Immunol. Med. Microb. 43, 295-300. 